\title{
The shifting role of the listeners in the mediamorphosis process of culture radio: A case study of Jodhipati 106.1 FM
}

\section{Pergeseran peran pendengar pada proses mediamorfosis radio budaya: Studi kasus di Jodhipati 106.1 FM}

\author{
$\underline{Z a i n a l ~ A b i d i n ~ A c h m a d ~}^{1}$ \& Rachmah Ida ${ }^{2}$ \\ ${ }^{1}$ Department of Social Sciences, Faculty of Social and Political Science, Universitas Airlangga \\ ${ }^{2}$ Department of Communication Sciences, Faculty of Social and Political Science, \\ Universitas Airlangga \\ Address: Jalan Dharmawangsa Dalam, Surabaya, East Java 60286 \\ E-mail: zainal.abidin.achmad-2015@fisip.unair.ac.id
}

\begin{abstract}
The adaptation of the use of communication technology towards media convergence (mediamorphosis) makes it a necessity for radio to change. Jodhipati FM, a commercial radio station in Nganjuk Regency which declared its identity as a Javanese cultural radio station, has also made the change. The uniqueness of Jodhipati FM to broadcast $100 \%$ Javanese cultural programs originated from the demands of listeners to listen to the wayang kulit (leather puppet) program. The close interaction and relationships between the listeners and radio management has made every change in Jodhipati FM driven by the interests of the listeners. This qualitative research collected data through a virtual ethnography supplemented by participant observation and in-depth interviews with nine informants. The results found there to be a mediamorphosis pattern that explains the stages of Jodhipati FM's change and the influence of the listeners' demands, from the early history of its establishment through to the present. At present, Jodhipati FM uses Facebook, streaming and WhatsApp as broadcast support. In interactive engagement between the listeners and radio management in the virtual world, both parties have an equal role as media producers. In the life of a networked society, the listener experiences a shift in role and characteristics. Apart from acting as the media producer, the radio listeners are involved in programming, they are free to criticize and they are also free to look for sponsors and advertisements. The characteristics of the listener have also changed. They become physically visible, their voices are heard, their personalities are revealed, they live in various social networks, age restrictions disappear, there are no territorial boundaries and there are no time limits. As a cultural radio station, Jodhipati FM has the advantage of being able to preserve and spread Javanese culture throughout the world.
\end{abstract}

Keywords: culture radio; mediamorphosis; network society; virtual ethnography

\begin{abstract}
Abstrak
Adaptasi pemanfaatan teknologi komunikasi menuju konvergensi media (mediamorfosis) adalah keniscayaan bagi radio siaran. Perubahan tersebut juga dilakukan oleh Jodhipati FM, sebuah radio di Kabupaten Nganjuk yang menyatakan identitasnya sebagai radio budaya Jawa. Keunikan Jodhipati FM untuk menyiarkan 100\% program budaya Jawa, berawal dari tuntutan pendengar untuk mendengar siaran program wayang kulit. Interaksi dan relasi yang akrab antara pendengar dengan manajemen radio, mengakibatkan setiap perubahan Jodhipati FM banyak didorong oleh kepentingan pendengar. Penelitian kualitatif ini mengumpulkan data melalui etnografi virtual dilengkapi dengan observasi partisipan dan wawancara mendalam terhadap sembilan informan. Hasil penelitian menemukan pola mediamorfosis yang menjelaskan tahap perubahan Jodhipati FM yang dipengaruhi desakan pendengar, dari awal berdiri hingga sekarang. Saat ini facebook, streaming dan whatsapp digunakan untuk mendukung siaran. Seiring keterlibatan interaktif antara pendengar dan manajemen radio di dunia virtual, keduanya memiliki peran yang setara sebagai produsen media. Dalam kehidupan masyarakat jaringan, pendengar mengalami pergeseran peran dan karakteristik. Pendengar berperan menjadi produsen media, terlibat dalam penyusunan program siaran, leluasa memberikan kritik, turut mencari sponsor dan iklan. Karakteristik pendengar juga berubah. Mereka menjadi dapat dilihat fisiknya, didengar suaranya, diketahui kepribadiannya, hidup berjejaring melalui berbagai aplikasi jejaring sosial, tidak kenal batasan umur, batas wilayah dan batas waktu. Sebagai radio budaya, Jodhipati FM memiliki keunggulan karena mampu melestarikan dan menyebarluaskan budaya Jawa ke penjuru dunia.
\end{abstract}

Kata kunci: etnografi virtual; masyarakat jaringan; mediamorfosis; radio budaya 


\section{Introduction}

Change is a necessity. The same thing happens in communication technology, continually changing and evolving. For commercial radio, if they do not keep up with technological developments, their lives will be crushed. They will inevitably have to adapt and take advantage of technological advances. Most commercial radio survival, also determined by the ability to adapt to technological advances (Achmad \& Alamiyah 2015). They are required to mediamorphosis to survive and win the competition. Commercial radio competitions cannot avoid influencing listeners' demands to get useful and liked broadcasts, such as great songs, entertaining programs, clear sound quality, and programs that match the needs of listeners. As a consequence of these demands, the radio is obliged to continue to develop and improve the professional performance (input) and the quality of the broadcast (output) to suit the social dynamics. Radio is required to be ready to make changes at any time.

Many people say that successful commercial radio is a radio that gets huge revenue through advertising. That opinion is not entirely true nor false. Because many other supporting factors are interconnected with each other, among others: good programs, large number of listeners, passion from managers, creativity of workers, good earnings, reliable broadcast technology, interactive audience, ability to change, management has a quality, and a conducive socio-political climate (Kitley 2000, Kitley 2003). However, most noticed is the ability of the radio to change and adapt to the advancement of communication technology.

When commercial radio subjected to external pressure (such as listeners demands, regulatory changes, culture changes) with the advent of communications technology (internet, digital broadcasting, mobile applications), they are adaptively self-organizing (changing programs, changing segments, using the internet, utilizing mobile application) in an effort to maintain survival. This process is called the essence of mediamorphosis (Fidler 1997). Mediamorphosis is created from two words: media and morphosis; (a scientific term used to describe how organisms or parts change) to create a new word to describe the simultaneous changes occurring in the media world today (Biagi 2017). The new form of media with a new way of working is as an evolution of the media that have been present earlier. The evolution of media functions depends on the evolution of human life around it (McFadden 2012).

This study examines the mediamorphosis process conducted by Jodhipati FM in Nganjuk, one of the commercial radio in East Java that switched formats from Indonesian pop radio to Javanese culture radio. During the process of switching formats, Jodhipati FM at once faced with the growing condition of communication technology. So we can see the form of adaptation by Jodhipati FM in exploiting the development of media convergence (mediamorphosis) and the role of Jodhipati FM listeners during the process.

Since the enactment of the Broadcasting Act No. 32, in 2002, several new radios emerged. One hundred sixty-four commercial radios have permanent licenses and operate in East Java (KPID East Java 2017), but not many of them have positioned as culture radio (PRSSNI East Java 2018). One that has successful positioning as culture radio is Jodhipati FM. Jodhipati FM creatively and innovatively determines segmentation. Determination of segments with different ages and types of work can direct creativity to make broadcast programs (Barber, 2010). Because the field of radio business is marketing ideas, the most important thing is to determine the right format and position (Sweeting 2007, Inkinen \& Tuominen 2013). Then Jodhipati FM adjusts the character and culture of its audience to determine its broadcast program (Walker 2004).

Jodhipati FM is cautious when conducting positioning strategies in order not to violate existing regulations, both in terms of licensing (Harianja 2009) and broadcast content (Indonesian Broadcast Commission 2011). At the beginning of the establishment in 2003, this radio has a standard format, with the dominance of the song Nostalgia and Pop Indonesia. Then in 2008, it turned into a radio that has information and educational format, with the dominance of Gending Javanese music, as well as using Kromo Javanese language as a broadcast language. Jodhipati FM deserves to be studied because 
of its adaptability to the development of communication technology. Although its positioning is a cultured radio with the Javanese language, this study elaborates how radio listeners play an essential role in the Mediamorphosis process (the use of communication technology for broadcasting) and the making of radio programs through dialogue, criticism and discussion in communication media (Facebook, chat rooms and WhatsApp groups).

\section{Research Method}

This qualitative research uses virtual ethnography method based on the consideration that in the current era of media convergence, radio listeners do not only live in the real world but also the virtual world. This decision was chosen so that researchers can identify the behaviour, content of the communication and social relations of radio listeners, through direct contact at certain times (adjusting data needs and analysis) as inhabitants of the virtual world (Hine 2000).

Researchers conduct participant observation by involving ourselves in the broadcast process (to observe the situation and broadcast activities and get an atmosphere of audience interaction with broadcasters) and engage ourselves actively in social media Facebook, Instagram, chat room and WhatsApp group (to observe social context, communication behaviour, contents of communication and social relations that are built between listeners, broadcasters and management of Jodhipati FM). In some parts, researchers conducted in-depth interviews to obtain opinions, perceptions and attitudes of the research subjects in the mediamorphosis process and in making culture broadcast programs.

Researchers used five strategic steps as commonly used in virtual ethnography (Achmad \& Ida 2018). The first step, we identify groups and communities of listeners to be able to enter and become part of it. The researchers entered the WhatsApp group, followed a Facebook account and Instagram account with the approval of the group admin and approval from the director of Jodhipati FM. The second step, we negotiate access After becoming part of the community (different from the practice of conventional ethnography that conducts research and observation without the need to get recognition of the presence of researchers from research subjects). We explain the purpose of the research, the role of researchers and research subjects, and offer the benefits of research for the research subjects. At this stage, we had the opportunity to be interviewed by Jodhipati FM announcer through an on-air broadcast.

The third step, the direct involvement of researchers in the virtual world through participant observation, we can observe relational phenomena, conflicts, findings and depth of information. As a case study, virtual ethnographic research at Jodhipati FM is useful to improve the use of theory or to provide new theoretical insights. Researchers became an active part of the network society that surrounds Jodhipati FM. Researchers streamed directly through the official website (https://jodhipatifm.co.id) became an active follower of Facebook (https://www.facebook.com/jodhipatifm/), downloaded the mobile radio streaming app for the android phone via play store (https://play.google.com/store/ apps/details?id=appinventor.ai_nurceper1.RADIO_JODHIPATI\&hl=in), and became a member of WhatsApp group (Sanak Kadang Jodhipati). We observe ethnographic records of communication contents, communicating parties, time of communication, including the language used.

The fourth step, researchers conducted an interactive in-depth interview. We explored the hidden meaning with the subject, verified each finding before giving further analysis and giving criticism. This ethnographic interviewing process referred to as "shared experience" and this is what distinguishes it from other research interview practices because interviews in ethnography provide benefits in terms of depth and wealth of results. Interviews conducted online (using chat, real-time interaction) and offline (face to face interaction). The fifth step, researchers return the analysis of the research to the community. It is different from conventional ethnography which tends to follow the flow of the interview and is followed by analysis; Virtual ethnography tends to be critical, ensuring that every development of theory and findings returned to the research subjects. It is essential if the research aims to produce emancipator changes.

This study collects data on natural conditions from primary data sources (DeWalt \& DeWalt 2002), the data collection techniques relying on participant observation, in-depth interviews and documentation. 
As ethnographers, researchers work with informants as a subjects to produce a description of the culture. All nine informants speak and behave according to their understanding and experience. As the main instrument of research, researchers set the focus of the research, selected the appropriate subjects as data sources, conducted the process of collecting data, considered the quality of the data, carried out data analysis, interpreted the data and compiled conclusions.

As the basic strategy of virtual ethnographic research, which is critical, it offers an emancipator agenda by providing opportunities for research subjects to identify and evaluate this study. Does this study give influence and hope to the lives of subjects (work, income, network)? Can the subjects play a role in supporting the changes offered or they are involved in these changes?

Some of the change issues offered in this study include: 1) encouraging the use of technological developments (streaming, Facebook, WhatsApp) to support the quality and coverage of broadcasts, expand segmentation, reach more listeners, increase ad revenue, and efficient in financing the program, 2) giving awareness and confidence to radio listeners, that they have a role in the production process of radio broadcasts through their activities in the network society (chat rooms, WhatsApp groups, comments on Facebook and comments on Instagram), they can criticize and change broadcast programs as required, 3) provide the ability to disseminate Javanese culture and pass it on to future generations, and 4) the activities of listeners in the virtual world also provide opportunities for more significant interaction and communication, adding friendship to unlimited business networks.

\section{Results and Discussion}

Jodhipati FM's adaptation to the use of communication technology, is a reinforcement of the thesis of several theories of social science and communication, including: Marshall McLuhan with the theory of technology determinism (Levinson 1999, Wardrip-Fruin \& Montfort 2003, Marchessault 2005), Daniel Bell with the theory of post-industrial society (Bell 1999), Stuart Hall with the theory of culture studies (Hall 1996, Davis 2004), Roger Fidler with the theory mediamorphosis (Fidler 1997, Yzer \& Southwell 2008), Walter Benjamin with the sociology of the audience theory (Steiner 2011, Kang 2014), and Manuel Castells with the theory of network society (Castells 2010).

Marshall McLuhan's theory of technological determinism explains that technology determines many other changes that occur in human life, namely the changing of ways, patterns, places and times of communication. Communication technology is a factor that is transforming human culture. The theory of post-industrial society, Daniel Bell, explaining that humans living in technological advances, must dominate information. So those who master the information will have power. Theory of cultural studies Stuart Hall describes the human being and the use of new communication technologies, changing the form of communication from consumers to media producers. Roger Fidler's theory of mediamorphosis explains that traditional forms of mass media (radio, television, newspapers, magazines, books, movies and audio recordings) are transforming with mediamorphosis toward digital and convergence and are called "New Communication Technology" and this process is inevitable. Manuel Castells' theory of network society explains that interconnected communication technology has a profound impact on the changing world of contemporary living. Many aspects of human life depend on the network, as their life is on the network. So those who master the network will have power.

The theory of network society has the power of human mapping dependence on networks (the internet). This theory recognizes the flow of Marxian conflict theory. Due to the mass media and internet life, there is class structure, power structure, and domination (Fuchs \& Sandoval 2013). In today's world-class system, radio as a traditional media can no longer be considered as the sole distributor of knowledge. The radio converges and connects to the network. Radio is not only connected to the listener but also connected with the public at large. Radio connection with the public occurs when the radio connects much information obtained from other nodes they have. While on the network, radio listeners transformed into media producers. 
Moreover, the power relations between information producers (radio management) and listeners, can be parallel or even reverse. The characteristics of listeners who used to "sit and hear" changed to "make and do". Radio broadcasts now a product of two parties, both who live in the broadcast room and who receive the broadcast. They have many ways and tools to act as media producers.

Jodhipati FM is called a cultured radio and is selected for study, as it has the following criteria: 1) has a broadcasting license; 2) having culture programs with a duration of more than four hours a day or more than $25 \%$ of the total broadcasting hours; 3 ) using the local language as a broadcast language; 4) owns a website, Facebook account, and broadcasts streaming radio; and 5) have a number of active listeners and interact on off-air activities, on-air broadcasts and social media.

\section{Mediamorphosis process of Jodhipati FM}

According to the theory of mediamorphosis, the transformation of traditional forms of media into media convergence is an inevitable process. The demands of its listeners more influence the process of mediamorphosis of Jodhipati FM. The radio listeners are very active in social media, especially on the superior program broadcast. They experience a change in how to communicate; pattern, place, time and motivation to communicate. They have other lives as members of the network society because they are present and actively communicate via chat room on the streaming website (www. jodhipatifm.co.id), Facebook comments (https://www.facebook.com/jodhipatifm/) and WhatsApp group (Sanak Kadang Jodhipati).

\footnotetext{
"Since Facebook was launched, then we realized the potential of Jodhipati FM radio listeners who like broadcasting culture, especially shadow puppets. It turns out that shadow puppet fans are widespread not only in Nganjuk and its surroundings. The listeners gave much feedback through comments on Facebook so that Jodhipati FM immediately built a streaming broadcast system to be heard outside the Nganjuk area. Finally, we built the streaming technology with inexpensive fees, depending on the bandwidth and the number of gadgets connected to our server. At first, we only opened 50 connections. However, now with the number of connected more than 200 gadgets, our servers are overwhelmed, so the streaming is intermittent (Widodo 2018)."
}

In each process ofdeveloping JodhipatiFM, listeners haveavery vitalrole. Since the changein positioning becomes a radio culture, until the development of streaming broadcasts. Listeners are the ones who give criticism, correction, demands and solutions at each stage of the change. As shown in Figure 1.

Furthermore, the activities and interactions of listeners within the network society become more widespread. Age segment boundaries are blurred. Listeners become part of the media producers. The listener's home region is also increasingly unlimited (Achmad 2016). What makes Jodhipati FM as a cultured radio able to survive and establish? The answer is the strength of the relationship between Jodhipati FM and its listeners. From the beginning, the relationship between Jodhipati FM and its listeners always based on "loyalty" and "trust" although the radio does not recognize and never see the audience. On the other hand, listeners also never know the owner of the broadcasting voice, do not know the manager and owner of Jodhipati FM. However, radio and listeners trust each other without getting to know each other (Bonini 2014).

Jodhipati FM now transformed into a participatory media. The presence of social networks, changing the relationship between management and listeners paradigmatically. The listeners become the real content of the radio. As McLuhan points out, "in electronic media, the user is the content" (Levinson 1999). The statement proves to be true today. Based on the development of radio technology, radio is indeed able to survive because its role seems to be social media and not just media messenger or content as Walter Benjamin stated that radio has a radical potential to play "social media" (Gilloch 2002). Radio should not be just a means to spread bourgeois culture or mere entertainment. Radio can be used to transform public relations with culture and politics (Déotte 2010).

Jodhipati FM much respects its listeners. Listeners have a "real" interest in radio, so they are not only informed in a top-down way. Radio listeners have not affected parties, and they should be positioned 
on a par with the broadcaster, though at different poles (broadcasters and listeners positioned as partners in content production). Jodhipati FM plays an electronic mediation tool for listeners who have the potential for active participation in broadcasts. Communication technology makes the distance between producers with media audiences getting closer (Benkler 2006). Internet and various social networking applications, providing a technology platform that transforms the communication between Jodhipati FM and its listeners.

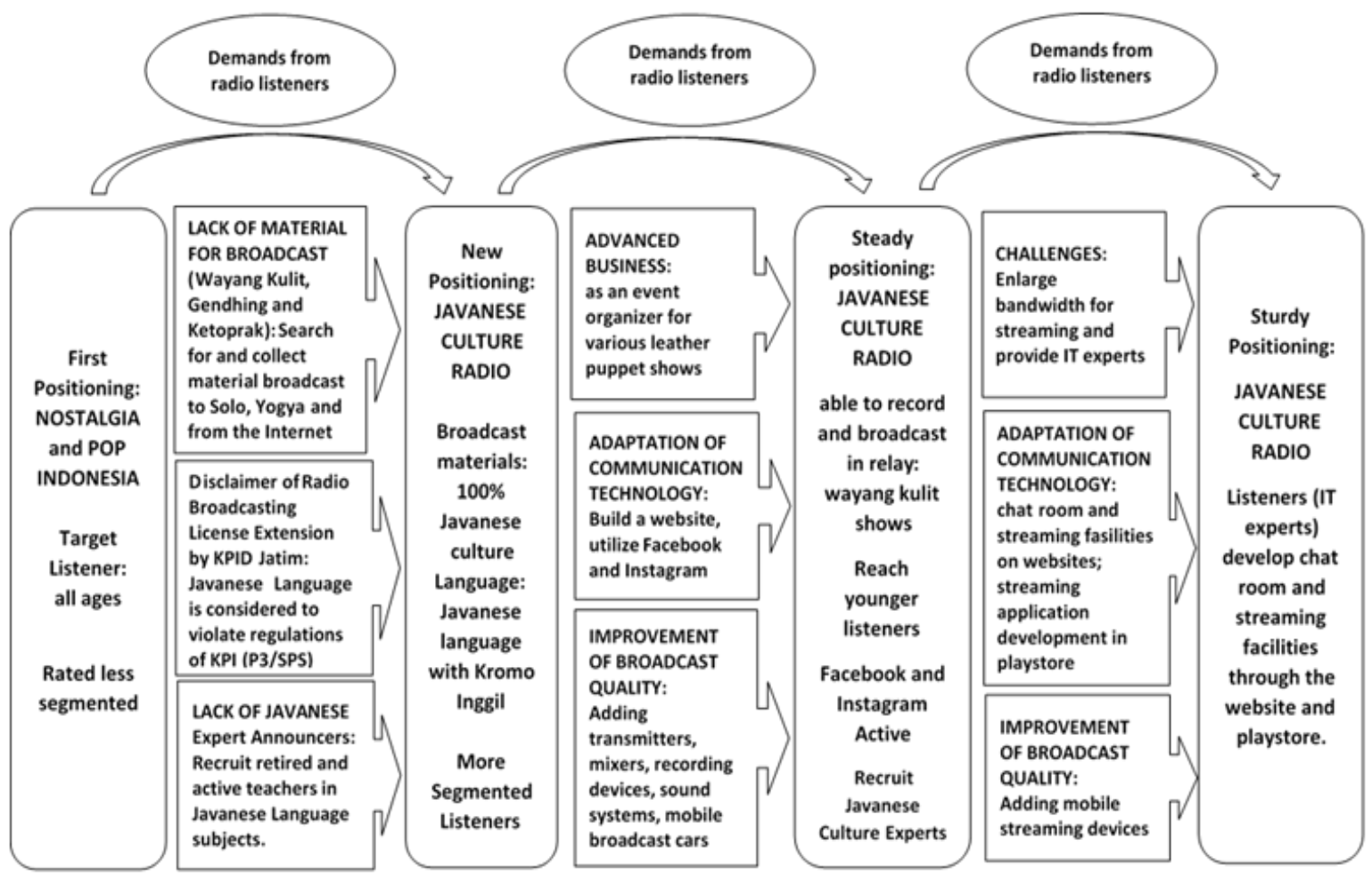

Figure 1.

Mediamorphosis process of Jodhipati FM

\section{Advantages as a culture radio}

The adaptation of Jodhipati FM to technological advancement has many advantages in cultural heritage, and strengthens its cultural identity as its vision, "Jodhipati Kumenyaring Budaya Nagari, serving as a source of information by upholding the culture of Java." Broadcasting using Javanese culture identity (Javanese language and traditional arts) makes Jodhipati FM a flagship program that should be owned by a cultured radio (Bosch 2014).

The advantage of Jodhipati FM is its secure positioning as a cultured radio, where its broadcast content is closely related to the local culture (Nguyen 2008) and the success of maintaining interaction with loyal listeners (Mytton 1992, King 2015, Wilkinson 2015). Listeners are positioned as witnesses to various events, through interviews, talk-show, and news coverage, which are broadcast. Jodhipati FM allows listeners to be heard (Benjamin 2005) and becomes a medium that reduces the distance between broadcasters and listeners, allowing the parties (copywriters, music directors, programmers, broadcasters and listeners) to participate as producers in the broadcast.

The advantage of Jodhipati FM positioning as a cultured radio, supported by the socio-culture conditions of the Nganjuk Regency, as one of the districts in East Java influenced by the Javanese culture of Mataraman (Sutarto \& Sudikan 2008). Voice art, dance art, literary arts, fine arts, traditional Javanese music arts are still well preserved. One way to preserve the culture is through the Wayang Kulit performance, which is often held by the people in Nganjuk and surrounding areas (Nganjuk, Kediri, Jombang, Tulungagung and Madiun). Based on data from Jodhipati FM, in a month there is two to three times Wayang Kulit performance. In certain months in Nganjuk, there is a Wayang Kulit 
performance every weekend. No wonder if Persatuan Pedalangan Indonesia (PEPADI) formed in Nganjuk. Similarly, the art of karawitan, tayub, and campursari, increasingly favoured by young people. They joined in various art groups in Nganjuk.

"Jodhipati FM is the pride of Nganjuk residents because it strengthens Nganjuk's identity as the centre of Javanese Culture in East Java. The format of a cultural radio similar to Jodhipati FM does not exist in Solo or Yogyakarta. Jodhipati FM plays an important role in increasing the quantity of wayang kulit performances in Nganjuk. The highest frequency of wayang kulit staging in Nganjuk Regency was in 2008, with 81 performances in one year. This number is higher than Solo, known as the mecca of puppetry. PEPADINganjuk obtained the data based on the permission of the shadow puppet show from the Nganjuk District Police Station. Besides that, it was recognized by many masterminds that the audience of the wayang kulit show in Nganjuk had a high appreciation for the arts and culture, not merely as entertainment and performances (Harmadi 2018)."

\section{Culture program development at Jodhipati FM}

Live performance of Wayang Kulit is the most popular, most listened to and most advertising programs at Jodhipati FM. All programs broadcasted in Javanese Kromo (Madya and Inggil). Some of its excellent programs include: Sunaring Ati Program is an Islamic da'wah event; SAMPUR Program (Sangu Makarya Purih Rahayu) is a special broadcast of tayub song that became the unique art of Nganjuk; JODHIPATI Program (Jodhang Gendhing Pamareming Ati) is a Javanese gendhing that collaborated with stories of Java Cultures; SRIKATON Program (Campursari Klasik Maton) is a classic campursari music; The JANGGAN Program (Jagadhing Anak) is a program that aims to introduce fairy tales or stories to children at school age in order to instil noble minds; MACAPAT program, presented once a week with a duration of 3 hours with the aim to cultivate Javanese song (tembang) in order to remain appreciated and loved by the community. Compared to the other commercial radios in Nganjuk, only Jodhipati dares to broadcast $100 \%$ using the Javanese language, which distinguishes it from radio Nande FM, radio Jossh FM, radio Ersal FM, radio Megantara AM and radio Tasma FM.

Artists and culture figures need Jodhipati FM to disseminate and promote their artworks. Therefore, they need to adapt and modify the staging version of traditional art to produce a radio broadcast version (Rusdi, 2012). Broadcast radio as an audio media undeniably supports the development of traditional music arts. As a result, Jodhipati FM plays a role in growing song composers: dangdut and campursari with Javanese language lyrics. In using the sophistication of synthesizers, electone, keyboard or music applications for personal computers and laptops, traditional musical instruments can be mixed with other types of music The song composers have competed to create Javanese songs with a combination of various traditional and modern musical instruments, regardless the genre of music adopted (Raditya \& Frederick 2013).

As a result, songs with Javanese lyrics proliferated with the help of commercialization through radio broadcasts. Radio broadcasts are used to strengthen traditional arts. The connection of these parties (song composers, singers, broadcasters, music players, music directors, program managements) has encouraged the growth of Javanese language songs to adjust to market tastes. The study of media and its role in influencing socio-culture life is a part of cultural studies, because, through in-depth analysis, it provides information about the role of media in society (Allmark 2018).

Jodhipati FM can be listened to by the people of East Java within a radius of 200KM covering nine regions, namely Nganjuk regency, Kediri Regency, Kediri city, Jombang regency, Mojokerto regency, Lamongan regency, Bojonegoro Regency, Ngawi regency, and Madiun regency. Through the use of advanced digital technology, Jodhipati FM can also enjoy in various parts of the world via radio streaming. According to data from management, Jodhipati FM listeners are increasingly widespread across the world.

Changes in the use of technology have an impact on the habits of the listeners. Radio streaming is useful for preserving and developing Javanese culture. The use of streaming technology becomes a 
bridge between generations in enjoying Javanese culture. Transistor radio devices are replaced by mobile devices that have FM radio applications. As such, Jodhipati FM listeners now have a more comprehensive segmentation.

\begin{abstract}
"The idea of streaming broadcasts comes from listeners so that Jodhipati broadcasts can be heard overseas. The management responded well, then recruited special employees to handle IT and social media. Since Jodhipati FM used streaming broadcasts in 2010, many overseas listeners were able to listen to the broadcast. Most of them are native Indonesians who migrate abroad, including Suriname, Netherlands, China, Taiwan, Hong Kong, UAE, Saudi Arabia, Malaysia, Singapore, the UK, Germany and Japan (Noegroho 2018).”
\end{abstract}

Since Jodhipati FM introduced streaming technology, there has been a shift in the age, the social economy and the education of its listeners' segmentation. Streaming technology requires the availability of internet data packages so that additional expenditure is needed. Operating applications and understanding of the capabilities of mobile devices for browsing, downloading, uploading requires sufficient technological knowledge. The current segment of Jodhipati FM listeners is not only dominated by the 40 to 70 years age group embracing farmers and traditional traders; today's audience's age ranges from 16 years to 70 years, from students, teachers, lecturers, office employees and civil servants to online drivers.

\begin{abstract}
"When a transistor radio device becomes an item that is difficult to find in an electronics store and is replaced by a mobile phone that has an FM radio application, the listeners of Jodhipati FM are increasingly broad in their age segments and social-economic segments. If observed, in a coffee shop, at street vendors, in rice fields, at markets, at the pedicab base, at the base angkudes around Nganjuk, radio listeners who use cellphones, the number is huge. Their age is very diverse. They usually add active speakers that are small in shape, low in price, range from 30 thousand to 50 thousand rupiahs to dissipate sound output from a mobile phone. Generally, these speakers are locally made or made in China, the price is low, and the sound is loud. The mobile phones that we have are generally also cheap, the price ranges from 200 thousand to 500 thousand, the most important is the availability of FM radio applications (Nurngalim 2018)."
\end{abstract}

At this moment, the role of Jodhipati FM listeners becomes blurred. Streaming broadcasts, Facebook and WhatsApp have changed many things. Utilization of media convergence by Jodhipati FM, impact on shifting the role of listeners. Listeners become an active part in the programming and broadcasting process (as producers). Listeners become very familiar with radio management so that they can advise on the form, type, content, and name of the program. Listeners also become critical when there is a mistake in the broadcast process, giving input if the announcer is mistaken (usually delivered directly through the group WhatsApp). Jodhipati FM listeners stated their agreement that the use of broadcasting technology (convergence media), making them an essential part in the production of broadcast programs and have a sense of ownership over broadcast programs on Jodhipati FM. Jodhipati FM listeners recognize the benefits of radio streaming for the dissemination and inheritance of Javanese culture.

\title{
Conclusion
}

Mediamorphosis is the transformation of communication media that usually arises from complex interrelationships between perceived needs, competition and political pressure, and various social and technological innovations. The results of this study broaden definition that the transformation of any media due to inevitable consequences is called mediamorphosis.

Through analysis with network society theory, it concluded that the relationship that builds between listeners, management and radio programs, results in a change in the role and the characteristics of the listeners. Its roles characteristics are different from before and after living in the virtual world. In the past, radio listeners only served as consumers and received broadcast content without rejection. Now the role of the listener is shifted to be part of the media producers. In the past radio, listeners 
had the characteristics of the invisible, personal, and passive. Now turns into a public actor, visible, audible and networked. They live on the internet, visit many websites and interact through various social networking application. The activities and interactions of listeners within the network society become more widespread. Age segment boundaries are blurred.

The results of this study reinforce the thesis of radio survival in the era of media convergence. Radio can never die, but it changes shape due to advances in communication technology. Radio can coexist and live on the internet, Facebook, streaming and Instagram. The radio is still able to live by adapting to the use of communication technology.

The advantages of Jodhipati FM choosing its position as cultural radio include: preserving and spreading Javanese Culture to the world. The strength of this positioning strategy proves that local culture is the reason for consumers to choose certain media. As well as strengthening the thesis that listener loyalty can influence radio program changes.

\section{References}

Achmad ZA (2016) Teori Masyarakat Jaringan Manuel Castells. Surabaya: Unpublished. https:// www.academia.edu/26377163/Teori_Masyarakat_Jaringan_Manuel_Castells_Zainal_ Abidin_Achmad_.

Achmad ZA \& Alamiyah SS (2015) Relation Between Political Economic of Media with the Strategies for Radio Positioning to Maintain the Exixtence of Commercial Radio (Case Study of JJFM Radio in Surabaya). International Conference on Democacy and Accountability (ICoDA) 2015, Strengthening Democratic Accountability for Creating good Governance. Surabaya: Faculty of Social and Political Science, Universitas Airlangga, pp. 188-193.

Achmad ZA \& Ida R (2018) Etnografi virtual sebagai teknik pengumpulan data dan metode penelitian. The Journal of Society \& Media 2 (2):130. doi: 10.26740/jsm.v2n2.p130-145.

Allmark P (2018) Research Trends in Communication \& Media in the Digital Future. Surabaya: Communication Department, Faculty of Social and Political Science, Universitas Airlangga (Workshop on Research Methodology).

Barber S (2010) Smooth jazz: A case study in the relationships between commercial radio formats, audience research and music production. Radio Journal: International Studies in Broadcast \& Audio Media 8 (1):57-70. doi: 10.1386/rajo.8.1.51_1.

Bell D (1999) The Coming of Post-Industrial Society. Special An. New York: Basic Books.

Benjamin W (2005) Walter Benjamin, Selected Writings Volume 2, Part 2 1931-1934. MW Jennings, H Eiland, \& G Smith (eds). London: Belknap Press of Harvard University Press.

Benkler Y (2006) The wealth of networks. German Law Journal. doi: 10.1177/0894439307301373.

Biagi S (2017) Media/Impact: An Introduction to Mass Media. 12th edn. Boston: Cengage Learning.

Bonini T (2014) The new role of radio and its public in the age of social network sites. First Monday 19 (6). doi: http://dx.doi.org/10.5210/fm.v19i6.4311.

Bosch TE (2014) Commercial music radio, race and identity in South Africa. Media, Culture and Society 36 (7):901-915. doi: 10.1177/0163443714536076.

Castells M (2010) The Rise of the Network Society. Chicester, West Sussex: Wiley-Blackwell.

Davis H (2004) Understanding Stuart Hall. London: SAGE Publications Ltd. doi: 10.2307/2804260.

Déotte JL (2010) Au microphone: Dr. Walter Benjamin. Walter Benjamin et la création radiophonique (1929-1933) de Philippe Baudouin. Appareil, 10. http://journals.openedition. org/apparei1/958.

DeWalt KM \& DeWalt BR (2002) Participant Observation: A Guide for Fieldworkers. Walnut Creek: AltaMira Press.

Fidler R (1997) Mediamorphosis: Understanding New Media. Thousand Oaks: Pine Forge Press.

Fuchs C \& Sandoval M (2013) Critique, social media and the information society. Critique, Social Media and the Information Society, 1-268. doi: 10.4324/9780203764077. 
Gilloch G (2002) Walter Benjamin: Critical constellations, Choice. Cambridge: Polity Press.

Hall S (1996) StuartHall: Critical dialogues in cultural studies. Comedia. doi: 10.4324/9780203993262.

Harianja H (2009) Penyalahgunaan Izin Penyelenggaran Penyiaran Radio dan Akibat Hukumnya Berdasarkan UU No. 32 Tahun 2002 tentang Penyiaran. Universitas Sumatera Utara.

Harmadi (2018) [Personal Communication] 14 November. Nganjuk: Humas Persatuan Pedalangan Indonesia (PEPADI) Kabupaten Nganjuk.

Hine C (2000) Virtual Ethnography. London: Sage Publications Ltd.

Indonesian Broadcast Commission (2011) Siaran Pers Dialog Uji Publik Pedoman Perilaku Penyiaran Dan Standar Program Siaran (P3SPS), Siaran Pers. Available at: https://www.kpi.go.id/ index.php/id/siaran-pers/3050-siaran-pers-dialog-uji-publik-pedoman-perilaku-penyiarandan-standar-program-siaran-p3sps (Accessed: 22 November 2017).

Inkinen E \& Tuominen A (2013) Brand Image of Radio Nostalgia in Finland. Haaha-Helia University of Applied Sciences.

Kang J (2014) Walter Benjamin and The Media: The Spectacle of Modernity. Cambridge: Polity Press.

King G (2015) Hearing community radio listeners: A storytelling approach for community media audience research. Participations, Journal of Audience and Reception Studies 12 (2):121136. http://www.participations.org/Volume 12/Issue 2/7.pdf.

Kitley P (2000) Television, Nation, and Culture in Indonesia. Athens: Ohio University Center for International Studies.

Kitley P (ed) (2003) Television, Regulation and Civil Society in Asia. London: RoutledgeCurzon.

KPID East Java (2017) Data Lembaga Penyiaran Swasta Radio di Jawa Timur 2017. Surabaya: Komisi Penyiaran Indonesia Daerah Jawa Timur, p. 4.

Levinson P (1999) Digitial McLuhan, a Guide to the Information Millennium. London: Routledge.

Marchessault J (2005) Marshall McLuhan. Journal of Chemical Information and Modeling. doi: 10.1017/CBO9781107415324.004.

McFadden JB (2012) Understanding media and culture: An introduction to mass communication. M Libraries. doi: https://doi.org/10.24926/8668.2601.

Mytton G (1992) Handbook on Radio and Television Audience Research. London: International Broadcasting Audience Research BBC World Service.

Nguyen TTT (2008) The Role of Radio and TV in the Life of Ethnic Minorities in Vietnam: Case Study: the H'mong People in Lao Cai and Lai Chau Province. University of Tromsø. http:// hdl.handle.net/10037/1547.

Noegroho DH (2018) [Personal Communication]. 13 November. Nganjuk: Programmer Radio Jodhipati FM.

Nurngalim, R. (2018) [Personal Communication]. 12 November. Nganjuk: Loyal Listener Radio Jodhipati FM.

PRSSNI East Java (2018) Profil Anggota PRSSNI Jawa Timur. [Accessed 29 June 2018]. http:// www.radiojatim.com/index.php?option $=$ com_content\&view $=$ article\&id=1\&Itemid=154 .

Raditya MHB \& Frederick WH (2013) Hibriditas musik dangdut dalam masyarakat urban. Journal of Urban Society's Arts 13 (1):1-14.

Rusdi F (2012) Bahasa Daerah dan Industri Radio: Menggagas Pencitraan Berbasis Kearifan Lokal, pp. 347-356.

Sutarto A \& Sudikan SY (eds) (2008) Pemetaan Kebudayaan di Provinsi Jawa Timur: Sebuah Upaya Pencarian Nilai-Nilai Positif. Jember: Biro Mental Propinsi dan Kompyawisda Jatim.

Sweeting A (2007) The Costs of Product Repositioning: The Case of Format Switching. Manuscript.

Steiner U (2011) Walter Benjamin: an introduction to his work and thought. Choice 48 (5):898. http://ezaccess.libraries.psu.edu/login?url=http://search.proquest.com/docview/835068212? accountid $=13158$. 
Walker J (2004) Rebels on the Air: An Alternative History of Radio in America. 2nd edn. New York: New York University Press.

Wardrip-Fruin N \& Montfort N (2003) The New Media Reader. Cambridge: MIT Press.

Widodo D (2018) [Personal Communication]. 12 November. Nganjuk: Direktur Radio Jodhipati FM.

Wilkinson C (2015) Young People, Community Radio and Urban Life. Geography Compass 9 (3):127-139. doi: $10.1111 /$ gec3.12197.

Yzer MC \& Southwell BG (2008) New communication technologies, old questions. American Behavioral Scientist 52 (1):8-20. doi: 10.1177/0002764208321338. 